\title{
An Adult Case of Hemiplegia, Aphasia, and Hemispheric Atrophy Associated with Febrile Status Epilepticus
}

\author{
Tameto Naoi ${ }^{1}$, Mitsuya Morita ${ }^{1,2}$ and Kansuke Koyama ${ }^{3}$
}

\begin{abstract}
:
A 43-year-old man with a preceding infection was transferred to our hospital for febrile status epilepticus (SE). Although treatment for SE was immediately initiated, it failed. Therefore, continuous anesthetics treatment with mechanical ventilation was initiated. No epileptic discharge was found on an electroencephalogram. However, total aphasia and right hemiplegia due to left hemispheric swelling were noted on day 5. His aphasia and hemiplegia did not improve. The mechanism underlying the hemispheric involvement remains unclear. The initial diagnosis should be made with care in patients with febrile SE; furthermore, intensive treatment should be administered in the acute phase.
\end{abstract}

Key words: status epilepticus, hemispheric atrophy, acute encephalopathy, HHE syndrome, Rasmussen encephalitis

(Intern Med 60: 1089-1094, 2021)

(DOI: 10.2169/internalmedicine.5175-20)

\section{Introduction}

Refractory status epilepticus (SE) occasionally results in radiological changes on magnetic resonance imaging (MRI) $(1,2)$. MRI abnormality was detected in $11.6 \%(2)$, $20.6 \%$ (3), $29.4 \%$ (1), and $52.9 \%$ (4) of patients with SE. The signal changes on MRI were characterized by increased $\mathrm{T} 2$, fluid-attenuated inversion recovery (FLAIR), and diffusion-weighted imaging (DWI) signals and a variable degree of reduction in the apparent diffusion coefficient (ADC) (1-4). However, hemispheric involvement associated with SE is rare, and the underlying mechanism remains unclear in adults $(1-3,5)$. Whether SE has entered a postictal phase or if the lack of recovery is due to continuing SE following unsuccessful treatment is occasionally difficult to distinguish. Furthermore, if the SE has been caused by encephalopathy, additional immunotherapy is fundamental.

We herein report the clinical course of an adult patient with hemiplegia, aphasia, and hemispheric atrophy associated with febrile SE.

\section{Case Report}

A 43-year-old man with a history of symptoms compatible with an upper respiratory infectious disease, including a fever, cough, and general fatigue lasting for 3 days, was transferred to Jichi Medical Hospital for SE in summer 2010. In his 20s, he had had left-eye blindness due to falling in the absence of an epileptic episode. He had no other remarkable history of illness, including migraine, and no medication. He also had no familial history of epilepsy. He was right-handed. His body height/weight was $175.8 \mathrm{~cm} /$ $62.7 \mathrm{~kg}$.

On admission to our hospital, his body temperature was $38.8^{\circ} \mathrm{C}$. A neurological examination showed coma and generalized convulsive SE (GCSE). The convulsion started from the right side and spread to the left side, so focal to bilateral tonic-clonic seizure was considered. Bilateral upward eye deviation was noted. The Babinski reflex was observed in his right foot. Neck stiffness was not noticeable during the clinical course.

Table 1 shows the laboratory data on admission and cerebrospinal fluid on day 8 . The most deteriorated data for

${ }^{1}$ Rehabilitation Center, Jichi Medical University, Japan, ${ }^{2}$ Division of Neurology, Department of Medicine, Jichi Medical University, Japan and ${ }^{3}$ Division of Intensive Care, Department of Anesthesiology and Intensive Care Medicine, Jichi Medical University, Japan 
Table 1. Laboratory Findings on Admission and Cerebrospinal Fluid Finding on Day 8.

\begin{tabular}{|c|c|c|c|c|c|c|c|}
\hline \multicolumn{4}{|l|}{ Hematology } & \multicolumn{2}{|l|}{ Cerebrospinal fluid } & \multicolumn{2}{|c|}{ Arterial blood gas } \\
\hline white blood cell & $12,900 / \mu \mathrm{L}$ & ALT & $420 \mathrm{U} / \mathrm{L}$ & the initial/ end pressure & $14 / 11 \mathrm{cmH}_{2} \mathrm{O}$ & $\mathrm{pH}$ & 7.058 \\
\hline neutrophil & $8,165 / \mu \mathrm{L}$ & $\mathrm{LDH}$ & $434 \mathrm{U} / \mathrm{L}$ & lymphcyte & $3 / \mathrm{mm}^{3}$ & $\mathrm{PaO}_{2}$ & $85.9 \mathrm{mmHg}$ \\
\hline hemoglobin & $15.0 \mathrm{~g} / \mathrm{dL}$ & creatinine kinase & $162 \mathrm{U} / \mathrm{L}$ & neutrophil & $0 / \mathrm{mm}^{3}$ & $\mathrm{PaCO}_{2}$ & $62.1 \mathrm{mmHg}$ \\
\hline platelet & $22.0 \times 10^{4} / \mu \mathrm{L}$ & albumin & $4.4 \mathrm{~g} / \mathrm{dL}$ & protein & $33 \mathrm{mg} / \mathrm{dL}$ & $\mathrm{HCO}_{3}^{-}$ & $17.7 \mathrm{mmol} / \mathrm{L}$ \\
\hline Coagulation & & CRP & $0.01 \mathrm{mg} / \mathrm{dL}$ & glucose & $72 \mathrm{mg} / \mathrm{dL}$ & lactate & $14.0 \mathrm{mmol} / \mathrm{L}$ \\
\hline fibrinogen & $99 \mathrm{mg} / \mathrm{dL}$ & glucose & $259 \mathrm{mg} / \mathrm{dL}$ & $\mathrm{IgG}$ & $11.3 \mathrm{mg} / \mathrm{dL}$ & ammonia & $130.0 \mu \mathrm{mol} / \mathrm{L}$ \\
\hline FDP & $5.8 \mu \mathrm{g} / \mathrm{mL}$ & TSH & $1.48 \mu \mathrm{IU} / \mathrm{mL}$ & albumin & $35.6 \mathrm{mg} / \mathrm{dL}$ & & \\
\hline PT-INR & 1.2 & free $\mathrm{T} 3$ & $2.25 \mathrm{pg} / \mathrm{mL}$ & IgG index & 0.23 & & \\
\hline AT-III actibity & $75.20 \%$ & free $\mathrm{T} 4$ & $0.67 \mathrm{ng} / \mathrm{mL}$ & $\mathrm{ADA}$ & $3.1 \mathrm{U} / \mathrm{L}$ & & \\
\hline Biochemistory & & HBs antigen & negative & oligoclonal band & negative & & \\
\hline BUN & $18 \mathrm{mg} / \mathrm{dL}$ & HCV RNA & $5.4 \mathrm{LogIU} / \mathrm{mL}$ & interleukin-6 & $3.0 \mathrm{pg} / \mathrm{mL}$ & & \\
\hline creatinine & $1.42 \mathrm{mg} / \mathrm{dL}$ & $\mathrm{HIV} \mathrm{Ag/Ab}$ & negative & $\mathrm{TNF}-\alpha$ & undetectable & & \\
\hline sodium & $145 \mathrm{mEq}$ & RPR & negative & interleukin- $1 \beta$ & undetectable & & \\
\hline T Bil & $0.63 \mathrm{mg} / \mathrm{dL}$ & $\beta$-D-glucan & $15.7 \mathrm{pg} / \mathrm{mL}$ & urine drug triage & negative & & \\
\hline AST & $479 \mathrm{U} / \mathrm{L}$ & & & & & & \\
\hline
\end{tabular}

ADA: adenosine deaminase, AST: aspartate transaminase, ALT: alanine aminotransferase, AT III activity: antithrombin III activity, BUN: blood urea nitrogen, CRP: C-reactive protein, FDP: fibrin degradation products, HCV: hepatitis C virus, HIV: human immunodeficiency virus, LDH: lactate dehydrogenase, PTINR: prothrombin time-international normalized ratio, T Bil: total bilirubin, TNF- $\alpha$ : tumor necrosis factor- $\alpha$, TSH: thyroid-stimulating hormone, RPR: rapid plasma reagin

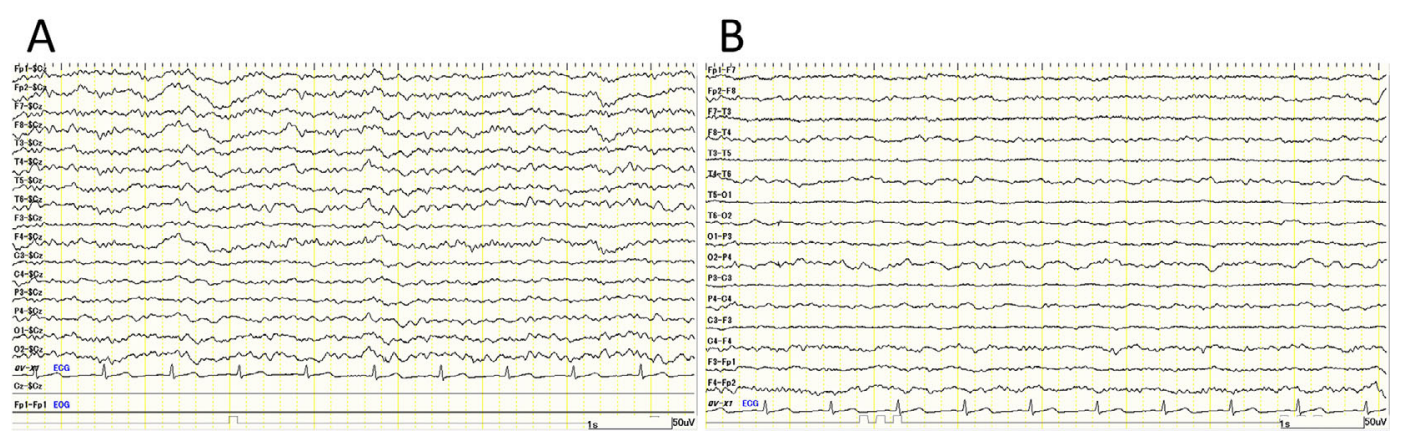

Figure 1. Electroencephalogram (EEG) findings on day 1 (A) and 4 (B). A) Slow waves were occasionally observed on day 1 . B) The EEG pattern became flattened without obvious epileptic discharge on day 4.

each finding were as follows: platelet $6.9 \times 10^{4} / \mu \mathrm{L}$ (day 2 ); creatinine $1.42 \mathrm{mg} / \mathrm{dL}$ (day 1); creatinine kinase, 15,454 U/ L (day 5); aspartate aminotransferase, 3,985 U/L (day 3); alanine aminotransferase, 1,645 U/L (day 3); prothrombin time-international normalized ratio (PT-INR), 1.86 (day 3); fibrin degradation products, $3.2 \mu \mathrm{g} / \mathrm{mL}$ (day 5), fibrinogen, $88 \mathrm{mg} / \mathrm{dL}$ (day 2); and antithrombin III activity, $44.2 \%$ (day 3 ). The patient rapidly developed disseminated intravascular coagulation (DIC), and multiorgan failure (MOF) involving the kidney, liver, central nervous system, and rhabdomyolysis. Therefore, other antiepiletic drugs (AEDs) were not initiated during the continuous infusion of midazolam, given concerns about adverse drug events.

Microscopy and culture of the sputum, cerebrospinal fluid (CSF), blood, and urine did not reveal the presence of any pathogens. Brain and thoracoabdominal computed tomography (CT) showed no abnormalities on admission. Intravenous midazolam, phenytoin, and phenobarbital were initi- ated; however, the GCSE failed to cease. Thus, the patient was put on mechanical ventilation with continuous anesthetic treatment. The total SE time was about six hours. An electroencephalogram (EEG) showed no epileptic discharge on days 1 or 4(Fig. 1), and bedside two-channel EEG monitoring showed no epileptic discharge; the anesthetics were thus tapered off. However, total aphasia and right hemiplegia associated with left hemispheric swelling were noted on day 5. The treatment regimen and clinical course of this case are summarized in Fig. 2, and the serial brain MRI results over the clinical course are shown in Fig. 3.

The fever and the laboratory findings gradually improved within two weeks. Seizure was not observed after the initial GCSE. However, cerebral hypervascularity was still observed on day 20 (Fig. 3, B3, B4). Furthermore, focal hyperperfusion was revealed on $\mathrm{N}$-isopropyl-p- $\left[{ }^{123} \mathrm{I}\right]$ iodoamphetamine ( ${ }^{123} \mathrm{I}$-IMP) single-photon-emission computed tomography (SPECT) on day 21 (Fig. 3, B5), although no epi- 


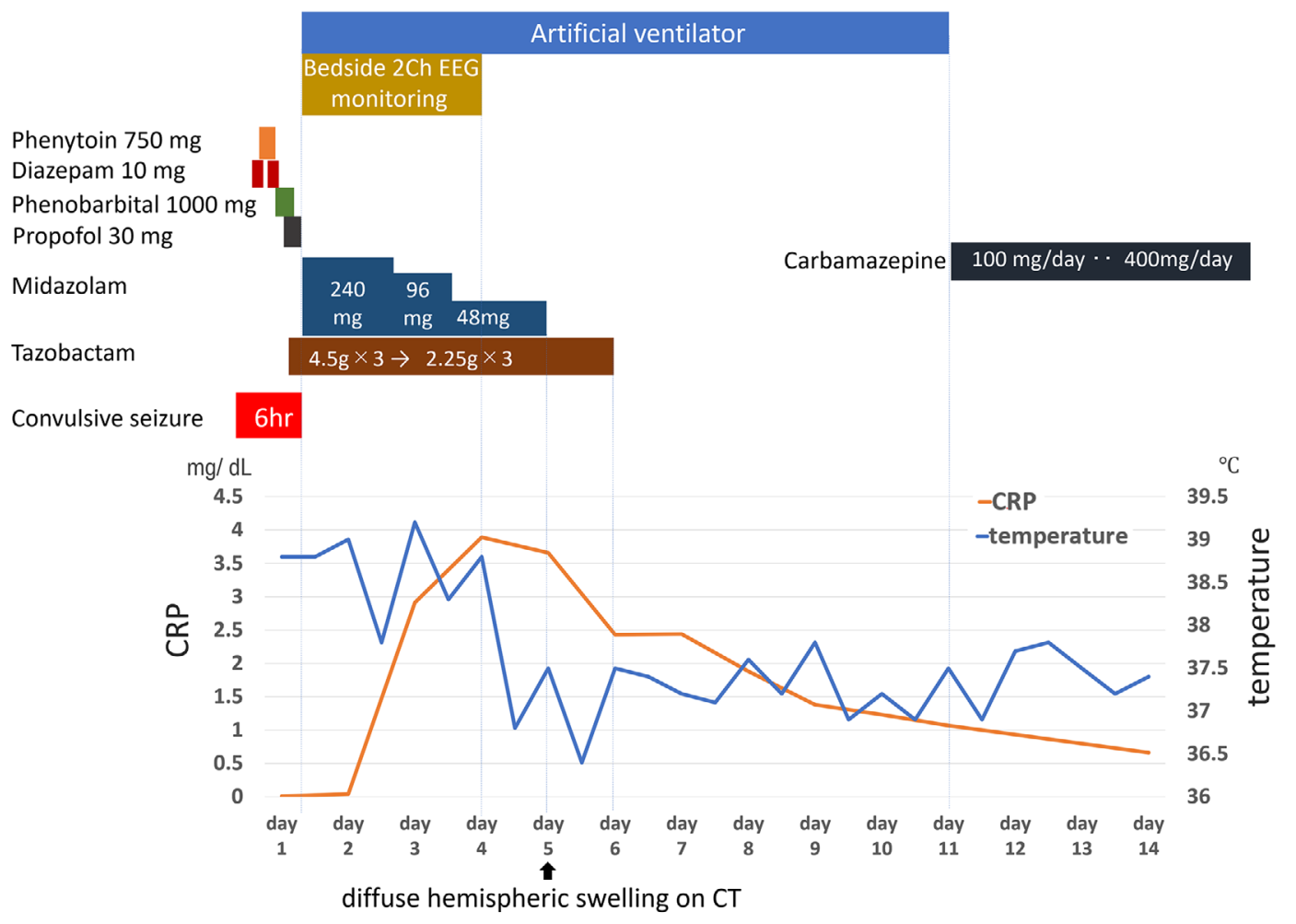

Figure 2. The clinical course and treatment regimen of the patient. The patient was treated with diazepam $10 \mathrm{mg}$ twice, intravenous phenytoin $750 \mathrm{mg}$, phenobarbital $1,000 \mathrm{mg}$, and propofol on day 1. However, status epilepticus did not cease, so he was placed on an artificial ventilator with the continuous intravenous administration of midazolam. Midazolam was terminated on day 5 because no epilepticus condition was observed. The patient was not treated with muscle relaxants, steroids, or immunoglobulins. Diffuse hemispheric swelling was found on CT on day 5.

leptic discharge was found on an EEG on the same day. He was discharged two months later.

Five years later, partial seizures occasionally appeared on his right side, probably due to the left hemispheric atrophic degeneration. His total aphasia and right hemiplegia did not improve. Suspecting a link to pediatric hemiconvulsionhemiplegia-epilepsy (HHE) syndrome, we checked for genetic abnormalities in carnitine O-palmitoyltransferase 2, adenosine A2A receptor, sodium voltage-gated channel alpha subunits 1 and 2, toll-like receptor 3, and RAN binding protein 2, which are known to contribute to HHE syndrome (6). However, no mutations or polymorphisms were identified in this case. The results of infectious factors for HHE were negative (Table 2) according to surveillance of acute encephalopathy at Tochigi Public Health Center.

\section{Discussion}

The present case rapidly developed DIC, MOF, and SE associated with left hemispheric swelling. Hyperperfusion consistent with signal changes on MRI without any epileptic discharge on an EEG was observed on day 21. Left hemispheric atrophy developed with sequelae later. Although a conclusive diagnosis was not made in this case, this patient's clinical course may help clarify the pathological condition and pathogenesis of the hemispheric involvement in patients with febrile SE.

With the proposed consensus (7), the clinical course of this patient was considered to reflect new-onset refractory SE (NORSE). Adult cases of hemispheric involvement associated with SE are rarely reported, with those available summarized in Table 3. No febrile condition was noted in the previously reported cases, and in all of these cases, hemispheric involvement was considered to be the result of SE, with various underlying etiologies considered to have triggered the hemispheric SE. Signal changes in the remote structures, such as the hippocampus and pulvinar, may have resulted from the SE activity (1).

Two possible pathogeneses for the hemispheric involvement were considered in this case. First, the patient had persistent NCSE after the control of the GCSE. NCSE may not be completely excluded even with the absence of epileptic discharge on a conventional EEG. In the present case, the right hemiplegia observed after the anesthetics were tapered was not Todd's paresis. Therefore, a more aggressive treatment was fundamental. The treatment in this case was not standard for SE. Even with the development of complications, such as MOF and DIC, other AEDs should not have been discontinued after the initiation of intravenous midazolam. A previous study suggested that aggressive treatment is necessary for SE, particularly in patients who develop systemic complications, as such cases are likely to have a fatal 


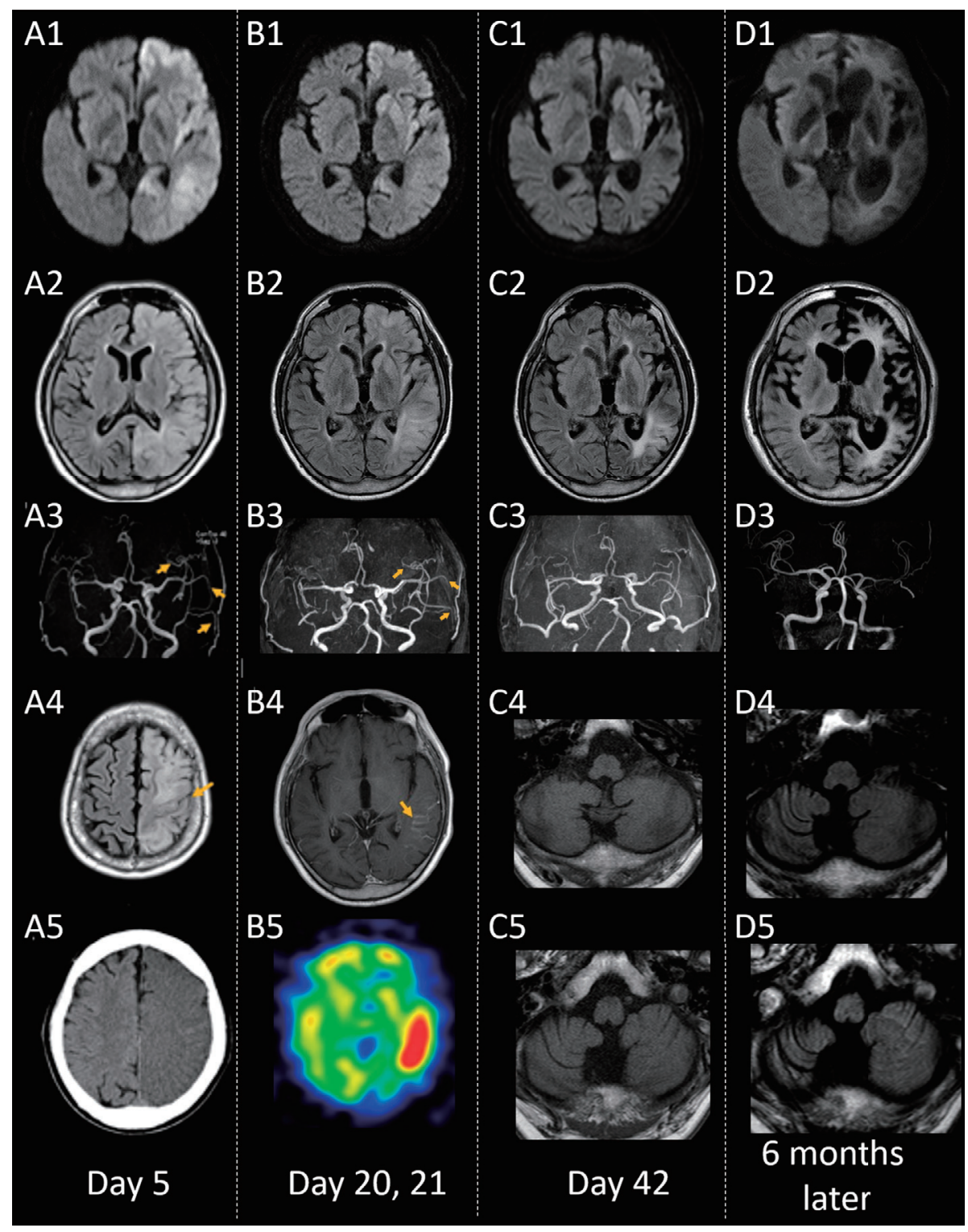

Figure 3. Serial radiological findings. A1-5) on day 5, B1-5) on days 20, 21, C1-5) on day 42, and D1-5) 6 months later. A1) Diffusion-weighted imaging (DWI) MRI showed a high intensity, particularly in the left frontal cortex, insula, temporoparietal area, hippocampus, and caudate nucleus on day 5. A2) Fluid-attenuated inversion recovery (FLAIR) MRI showed a high intensity in the same areas pointed out on the DWI sequence. A3) Hypervascularity on the left side was observed on MR angiography (MRA) (arrows). A4) The area around the central sulcus was spared on FLAIR sequence (arrow). A5) CT showed low-density diffuse swelling of the left hemisphere. B1, 2) High-intensity signals were still observed in the left frontal cortex, temporoparietal area, caudate nucleus, putamen, and around the hippocampus on DWI and FLAIR sequences. B3, 4) MRA and gadolinium-enhanced T1 imaging on day 20. Hypervascularity on the left side was still observed on MRA (arrows) and gadolinium-enhanced T1 imaging (arrow). B5) Hyperperfusion in the left temporal and parietal areas was observed on N-isopropyl-p- $\left[{ }^{123} \mathrm{I}\right]$ iodoamphetamine $\left({ }^{123} \mathrm{I}-\mathrm{IMP}\right)$ single-photon-emission computed tomography (SPECT) on day 21. C1, 2) DWI and FLAIR imaging on day 42. The cortical high-intensity signal on DWI had disappeared, accompanied by hemi-cerebral shrinking. The putamen and caudate nucleus still showed a high intensity on day 42 , while the left pulvinar showed a newly increased intensity on DWI. C3) MRA on day 42. Hypervascularity was less markedly observed. D1, 2) DWI and FLAIR imaging six months later. The high-intensity areas had disappeared, and progressing hemispheric atrophy was observed. D3) MRA six months later. The left cerebral blood vessels narrowed. $\mathrm{C} 4$, D4) Crossed cerebellar diaschisis was observed in the right cerebellum. 
Table 2. The Results of Infectious Factors in Blood (Day1) and Cerebrospinal Fluid Finding (Day 8).

\begin{tabular}{llll}
\hline human herpes virus 6 (LAMP) & negative & RS virus (PCR) & negative \\
human herpes virus 7 (LAMP) & negative & mumps virus (LAMP) & negative \\
herpes simplex virus 1 (LAMP) & negative & parainfluenza virus (PCR) & negative \\
herpes simplex virus 2 (LAMP) & negative & human metapneumovirus (PCR) & negative \\
enterovirus (PCR) & negative & human bocavirus (PCR) & negative \\
rhinovirus (PCR) & negative & & \\
\hline
\end{tabular}

LAMP: loop-mediated isothermal amplification, PCR: polymerase chain reaction, RS virus: respiratory syncytial virus

Table 3. Characteristics of Reported Cases of Hemispheric SE.

\begin{tabular}{|c|c|c|c|c|c|c|c|c|c|c|c|c|}
\hline \multirow{2}{*}{ Reference } & \multirow{2}{*}{ age } & \multirow{2}{*}{$\operatorname{sex}$} & \multirow{2}{*}{$\begin{array}{c}\text { SE } \\
\text { pattern } \\
\text { (duration) }\end{array}$} & \multirow{2}{*}{ fever } & \multirow{2}{*}{$\begin{array}{c}\text { possible } \\
\text { SE etiology }\end{array}$} & \multirow{2}{*}{ EEG } & \multirow{2}{*}{ CSF } & \multicolumn{2}{|c|}{ MRI timing (day) } & \multirow{2}{*}{$\begin{array}{l}\text { lesion } \\
\text { side }\end{array}$} & \multirow{2}{*}{$\begin{array}{c}\text { remote } \\
\text { structures }\end{array}$} & \multirow{2}{*}{ outcome } \\
\hline & & & & & & & & initial & follow-up & & & \\
\hline $\begin{array}{l}\text { The } \\
\text { present } \\
\text { case }\end{array}$ & 43 & M & $\begin{array}{l}\text { GCSE } \\
(6 \mathrm{~h})\end{array}$ & + & $\begin{array}{l}\text { preceding } \\
\text { infection } \\
\text { or } \\
\text { unknown } \\
\text { encephalopathy }\end{array}$ & $\begin{array}{l}\mathrm{R} \text { slow } \\
\text { waves }\end{array}$ & normal & 5 day & $\begin{array}{c}20,42 \\
\text { day } \\
6 \text { month }\end{array}$ & $\mathrm{L}$ & $\begin{array}{l}\text { L hippocampus } \\
\text { L putamen } \\
\text { L caudate } \\
\text { L pulvinar }\end{array}$ & $\begin{array}{c}\text { bedridden } \\
\mathrm{R} \text { hemiparesis } \\
\text { aphasia }\end{array}$ \\
\hline \multirow[t]{2}{*}{1} & 52 & $\mathrm{~F}$ & $\begin{array}{l}\text { GCSE } \\
(4 \mathrm{~h})\end{array}$ & ND & old stroke & $\begin{array}{l}\mathrm{R} \text { quiescent } \\
\text { background }\end{array}$ & normal & 4 day & 13 day & $\mathrm{R}$ & $\begin{array}{l}\mathrm{R} \text { thalamus, } \\
\text { CCD }\end{array}$ & stuporous \\
\hline & 22 & $\mathrm{~F}$ & $\begin{array}{l}\text { GCSE } \\
(6 \mathrm{~h})\end{array}$ & ND & $\begin{array}{l}\text { SLE, } \\
\text { L frontal } \\
\text { abscess }\end{array}$ & $\begin{array}{l}\text { L PLED, } \\
\text { frontal } \\
\text { spikes }\end{array}$ & ND & 14 days & $\begin{array}{c}22,32,42 \\
\text { day }\end{array}$ & $\mathrm{L}$ & $\begin{array}{l}\text { L basal ganglia } \\
\text { L thalamus } \\
\text { CCD }\end{array}$ & stuporous \\
\hline 2 & 36 & M & $\begin{array}{c}\text { GTC } \\
(<1 \text { day })\end{array}$ & ND & low AED levels & ND & ND & 1 day & ND & $\mathrm{R}$ & $\begin{array}{l}\mathrm{R} \text { thalamus } \\
\mathrm{L} \text { caudate } \mathrm{CCD}\end{array}$ & ND \\
\hline 3 & ND & ND & $\begin{array}{l}\text { GCSE } \\
\text { (11 days) }\end{array}$ & ND & ND & ND & ND & 15 day & ND & $\mathrm{L}$ & ND & ND \\
\hline 5 & 68 & $\mathrm{~F}$ & ND & ND & $\begin{array}{l}\text { hypernatremia, } \\
\text { dehydration }\end{array}$ & $\begin{array}{l}\text { spike and } \\
\text { wave }\end{array}$ & $\begin{array}{l}\text { mildly } \\
\text { increased } \\
\text { protein }\end{array}$ & 3 day & ND & $\mathrm{L}$ & $\mathrm{CCD}$ & ND \\
\hline
\end{tabular}

AED: antiepileptic drug, CCD: crossed cerebellar diaschisis, GCSE: generalized convulsive status epilepticus, GTC: generalized tonic clonic, ND: not described, PLED: periodic lateralized epileptiform discharge, SE: status epilepticus, EEG: electroencephalogram, F: female, L: left, M: male, R: right, CSF: cerebrospinal fluid

outcome (8). The dosage of anesthetics should be increased to show burst and suppression pattern on EEG as recommended $(8,9)$. Continuous EEG monitoring could not be performed because of the limitations of our facility. One study reported that continuous EEG monitoring could detect over $14 \%$ of patients with NCSE after convulsive SE had been controlled (10). In cases that are difficult to diagnose with NCSE, functional imaging, such as arterial spin labeling (ASL) and SPECT, may help detect NCSE (11).

The other possible pathogenesis of the hemispheric involvement was that the patient had encephalopathy, which resulted in refractory SE. Among young adults who present with NORSE, encephalopathy or encephalitis appear to trigger the refractory SE (12). HHE syndrome is associated with distinct radiological findings that initially appear normal but later become apparent, affecting a unilateral hemisphere (13). The present case exhibited all of the radiological features described by Mizuguchi et al. (13), except for the bright tree appearance on MRI. In adult patients with SE involving the hemisphere $(1-3,5)$, the cortical areas and ba- sal ganglia were mainly involved. However, pediatric HHE syndrome likely involves the subcortex. Considering the lack of any genetic or infectious abnormality associated with HHE syndrome in this case, the association between pediatric HHE syndrome and the present case remains unclear. Rasmussen encephalitis is also considered to be a differential diagnosis, although the progression in this case was rapid, compared with typical cases of Rasmussen encephalitis. Children are more prone to HHE syndrome and Rasmussen encephalitis than adults. In such cases, high-dose steroid IV or immunoglobulin IV (IVIg) should be administered in the acute phase (14). Fujita et al. reported a case of episodic aphasia and right hemiparesis due to encephalopathy accompanied by initial hypoperfusion and subsequent hyperperfusion on brain MRI using the ASL method (15). The authors suggested that the perfusion changes were reminiscent of those seen in patients with migraine with aura, rather than epilepsy.

Adult patients with febrile SE can rapidly develop hemispheric involvement, which results in severe sequelae. Con- 
sidering the hemispheric swelling observed on day 5, the combination of aggressive treatment for SE and immunotherapy, such as high-dose steroid with IVIg, should be considered within a few days. The initial diagnosis needs to careful assessment for encephalopathy/encephalitis in a more acute phase in patients with febrile SE.

Written informed consent to publish was obtained by the authors.

The authors state that they have no Conflict of Interest (COI).

\section{Acknowledgement}

We are sincerely grateful to Mizuguchi Masashi, Department of Developmental Medical Sciences, Graduate School of Medicine, The University of Tokyo, for the genetic analyses.

\section{References}

1. Huang YC, Weng HH, Tsai YT, et al. Periictal magnetic resonance imaging in status epilepticus. Epilepsy Res 86: 72-81, 2009.

2. Milligan TA, Zamani A, Bromfield E. Frequency and patterns of MRI abnormalities due to status epilepticus. Seizure 18: 104-108, 2009.

3. Goyal MK, Sinha S, Ravishankar S, Shivshankar JJ. Peri-ictal signal changes in seven patients with status epilepticus: interesting MRI observations. Neuroradiology 51: 151-161, 2009.

4. Kim JA, Chung J, Yoon PH, et al. transient MRI signal changes in patients with generalized tonic clonic seizures or SE: periictal diffusion weighted imaging. Am J Neuroradiol 22: 1149-1160, 2001.

5. Ferilli MAN, Brunetti V, Costantini EM, Della Marca G. Left hemispheric status epilepticus with crossed cerebellar diaschisis. J Neurol Neurosurg Psychiatry 89: 311-312, 2018.
6. Saitoh M, Shinohara M, Ishii A, et al. Clinical and genetic features of acute encephalopathy in children taking theophylline. Brain Dev 37: 463-470, 2015.

7. Hirsch LJ, Gaspard N, van Baalen A, et al. Proposed consensus definitions for new-onset refractory status epilepticus (NORSE), febrile infection-related epilepsy syndrome (FIRES), and related conditions. Epilepsia 59: 739-744, 2018.

8. Shneker BF, Fountain NB. Assessment of acute morbidity and mortality in nonconvulsive status epilepticus. Neurology 61: 10661073, 2003.

9. Tenkan Shinryo Guideline 2018 (Japanese guideline for the management of the epilepsy 2018). Igakushoin, Tokyo, 2018: 80-90 (in Japanese).

10. DeLorenzo RJ, Waterhouse EJ, Towne AR, et al. Persistent nonconvulsive status epilepticus after the control of convulsive status epilepticus. Epilepsia 39: 833-840, 1998.

11. Sugita K, Kamida T, Matsuta H, Shimomura T, Fujiki M. Usefulness of pulsed arterial spin-labeling MRI for localizing a seizure focus: a surgical case. Seizure 23: 318-320, 2014.

12. Gaspard N, Foreman BP, Alvarez V, et al. New-onset refractory status epilepticus: etiology, clinical features, and outcome. Neurology 85: 1604-1613, 2015.

13. Mizuguchi M, Yamanouchi H, Ichiyama T, Shiomi M. Acute encephalopathy associated with influenza and other viral infections. Acta Neurol Scand Suppl 186: 45-56, 2007.

14. Varadkar S, Bien CG, Kruse CA, et al. Rasmussen's encephalitis: clinical features, pathobiology, and treatment advances. Lancet Neurol 13: 195-205, 2014.

15. Fujita K, Osaki Y, Miyamoto R, et al. Neurologic attack and dynamic perfusion abnormality in neural intranuclear inclusion disease. Neurol Clin Pract 7: e39-e42, 2017.

The Internal Medicine is an Open Access journal distributed under the Creative Commons Attribution-NonCommercial-NoDerivatives 4.0 International License. To view the details of this license, please visit (https://creativecommons.org/licenses/ by-nc-nd/4.0/).

(C) 2021 The Japanese Society of Internal Medicine Intern Med 60: 1089-1094, 2021 